\title{
Development of tomato plants under different water tensions in soil during the productive stage
}

\section{Desarrollo de tomates sometidos a diferentes tensiones de agua en suelo durante el estado productivo}

\author{
Marlla de Oliveira Hott*, Edvaldo Fialho dos Reis, Victor Luiz, Souza Lima, Lucas Rosa Pereira, \\ Giovanni de Oliveira Garcia
}

\begin{abstract}
Tomato (Solanum lycopersicum L.) is one of the most cultivated and consumed fruit in the world. Water availability is one of the most important factors affecting tomato productivity, as fruit production is limited by water deficit and excess. Our objective was to evaluate the influence of five soil water tensions $(15,20,30,45$ and $60 \mathrm{kPa})$ during the productive stages of tomato plants grown in a greenhouse. The largest plants were obtained under the tension of $23.64 \mathrm{kPa}$. For variables such as the numbers of fruits produced per plant, productivity, mass, and fruit diameter, the highest results were obtained with $15 \mathrm{kPa}$ tension. The productivity under 15 $\mathrm{kPa}$ tension was $6.11 \mathrm{~kg} / \mathrm{plant}$, while that under $60 \mathrm{kPa}$ was $3.45 \mathrm{~kg} / \mathrm{plant}$, which corresponded to $43.5 \%$ more productivity than the lowest tension applied in the study. Therefore, soil water tensions can directly influence the productive development stage of tomato, with better results obtained under $15 \mathrm{kPa}$ tension.
\end{abstract}

Key words: Irrigation management, tensiometer, table tomato, fruit production.

\section{RESUMEN}

El tomate (Solanum lycopersicum L.) es una de las hortalizas más cultivadas y consumidas en el mundo. La disponibilidad hídrica puede ser considerada uno de los factores más importantes que afectan la productividad del tomate, pues la producción de frutos está limitada por el déficit y exceso de agua. Este trabajo tuvo como objetivo evaluar la influencia de cinco tensiones de agua en el suelo $(15,20,30,45$ y $60 \mathrm{kPa})$ durante el estadio productivo del tomate cultivado en casa vegetación. Las mayores plantas fueron obtenidas utilizando la tensión de 23,64 kPa. Para las variables número de frutos producidos por planta, productividad, masa y diámetro de frutos, los mayores resultados fueron obtenidos en la tensión de $15 \mathrm{kPa}$. La productividad en la tensión de 15 $\mathrm{kPa}$ fue de 6,11 kg por planta, mientras que a $60 \mathrm{kPa}$ fue de 3,45 kg por planta, lo que corresponde al 43,5\% más en productividad utilizando la menor tensión estudiada. Por lo tanto, diferentes tensiones de agua en el suelo pueden influenciar directamente el estadio de desarrollo productivo del tomate, con mejores resultados en la tensión de $15 \mathrm{kPa}$.

Palabras clave: Manejo de la irrigación, tensiómetro, tomate de mesa, producción de frutos.

\section{Introduction}

Tomato (Solanum lycopersicum L.) is one of the most cultivated and consumed fruits in the world. Its productivity and quality are closely linked to the appropriate use of water as well as the genetics, nutrition pattern, and the sanity of plants (Alvarenga, 2004; Santana and Vieira, 2010). Among these factors, the water supply directly affects the fruit production (Santana \& Vieira, 2010) in tomato plants, which makes the use of irrigation indispensable for its cultivation.

Although the localized irrigation system is more efficient for the application of water compared to other systems, in order to reduce wastage, it is necessary to manage water by using an appropriate amount of water at the right time depending on the crop type (Carvalho \& Oliveira, 2012). The maximum demand of water by tomato occurs during its flowering and fruit growth stages (Alvarenga, 2004). During the

Centro de Ciências Agrárias e Engenharias, Universidade Federal do Espírito Santo, Alegre, Espírito Santo, Brasil.

* Corresponding author: marllahott@yahoo.com.br; victor.1.lima@ufes.br

Fecha de Recepción: 11 junio, 2018.

Fecha de Aceptación: 05 agosto, 2018.

DOI: http://dx.doi.org/10.4067/S0718-34292018005001201. Publicado en línea: 3-diciembre-2018. 
fruiting stage, processing tomatoes have maximum productivity when irrigated at a tension of nearly $10 \mathrm{kPa}$; however, a reduction in productivity occurs when the soil water tension decreases, probably due to the lack of aeration in the root zone (Marouelli \& Silva, 2006).

The water supply to processing tomatoes should be managed according to the physiological stages, recommending the use of the tensions 35,12 and 15 $\mathrm{kPa}$ in the vegetative, fruiting and maturation stages, respectively (Marouelli \& Silva, 2007). Therefore, irrigation management based on the physiological stages can serve as a tool to increase crop productivity as well as to become an efficient method of using water. However, for table tomatoes, few studies have suggested that water tension maximizes productivity. The objective of this work was thus to evaluate the influence of five different soil water tensions on table tomato crop at the productive stage under greenhouse conditions.

\section{Material and Methods}

\section{Study site and soil preparation}

The experiment was conducted between April and July 2014 in a greenhouse located in the experimental area of the Centro de Ciências Agrárias e Engenharias of the Universidade Federal do Espírito Santo (CCAE-UFES) in Alegre, ES, Brazil. The climate of the study region is of type "Aw" with dry season in the winter, according to the classification of Köeppen (Koeppen, 1948), presenting with a temperature and average annual rainfall of $23^{\circ} \mathrm{C}$ and $1200 \mathrm{~mm}$, respectively.

The soil used in the experiment was classified as red-yellow latosol. Soil samples were collected in the experimental area of the CCAE-UFES from depths of 0-30 m. The soil was unstructured; it was sieved through a 4-mm sieve and homogenized. Soil correction was performed at 25 days before transplanting of the seedlings, according to the chemical analysis given in Table 1. After liming of the soil, $600 \mathrm{~g}$ of chicken bed was incorporated for every $50 \mathrm{~kg}$ of soil. The chemical fertilization of planting was performed directly in the pots, according to the methodology proposed by Novais et al. (1991) for controlled environment. During the experiment, additional fertilization was performed based on the Manual of Recommendation of Liming and Fertilization for the Espírito Santo State, $5^{\text {th }}$ approach (Prezotti et al., 2007).

\section{Experimental design}

The experiment was conducted in a completely randomized design, with five treatments and five replications. The experimental units were $50-\mathrm{L}$ pots containing soil with tomato plants ('Alambra' cv.). The pots were arranged on the ground with a spacing of $1.0 \times 0.5 \mathrm{~m}$ between rows and among plants, respectively.

The vegetative stage was considered as the period from the transplantation of the seedlings until the $33^{\text {rd }}$ day after transplanting (DAT). All experimental plots were also irrigated, maintaining the soil matric potential between the field capacity $(10 \mathrm{kPa})$ and the tension of $25 \mathrm{kPa}$.

During the productive stage of tomato from the $34^{\text {th }}$ DAT to the $90^{\text {th }}$ DAT, the treatments were applied, which consisted of five soil water tensions (15, $20,30,45$ and $60 \mathrm{kPa}$ ). The experimental plots were irrigated to maintain the matric potential between the field capacity $(10 \mathrm{kPa})$ and the tension required for each treatment. Thus, when the water tension in the soil reached the pre-established tension level, the irrigation was triggered. After the time required for the soil to return to the field capacity was reached, irrigation was suspended.

\section{Irrigation management}

Water was supplied through a drip irrigation system with a flow rate of $2 \mathrm{~L} / \mathrm{h}$. Two tensiometers

Table 1. Chemical attributes of the red-yellow latosol used as substrate for planting tomato.

\begin{tabular}{lccccccccc}
\hline $\mathrm{pH}$ & $\mathrm{P}$ & $\mathrm{K}$ & $\mathrm{Ca}$ & $\mathrm{Mg}$ & $\mathrm{Al}$ & $\mathrm{H}+\mathrm{Al}$ & $\mathrm{CEC}$ & $\mathrm{T}$ & $\mathrm{V}$ \\
\hline & $\mathrm{mg} \cdot \mathrm{dm}^{-3}$ & $\mathrm{mg} \cdot \mathrm{dm}^{-3}$ & $\mathrm{mg} \cdot \mathrm{dm}^{-3}$ & $\mathrm{mg} \cdot \mathrm{dm}^{-3}$ & $\mathrm{mg} \cdot \mathrm{dm}^{-3}$ & & $\mathrm{cmol}_{\mathrm{c}} \cdot \mathrm{dm}^{-3}$ & & $\%$ \\
\hline 5,3 & 3,0 & 69,0 & 1,2 & 0,8 & 0,1 & 4,5 & 6,7 & 2,3 & 32,7 \\
\hline
\end{tabular}


were installed per treatment at a depth of 0.2 $\mathrm{m}$, and the irrigation moment was determined by the mean of the tensiometers. To enable the use of tensiometers, the water retention curve was obtained according to Embrapa (2011). The curve was adjusted to the soil according to the model proposed by van Genuchten (1980). The volumetric moisture and the water replacement slide for each treatment were also determined. The irrigation time for the soil to return to the field capacity was determined by calculating the ratio of water replacement slide and the dripper flow rate, assuming $90 \%$ application efficiency (Bernarndo et al., 2009). The physical-water characteristics of the soil are described in Table 2.

Table 2. Physical-water characteristics of the soil. Field capacity (FC), wilting point (WP), available water (AW) and soil density (Ds).

\begin{tabular}{ccccccc}
\hline FC & WP & AW & Ds & Sand & Silt & Clay \\
\hline $\mathrm{m}^{3} \cdot \mathrm{m}^{-3}$ & $\mathrm{~m}^{3} \cdot \mathrm{m}^{-3}$ & $\mathrm{~m}^{3} \cdot \mathrm{m}^{-3}$ & $\mathrm{~g} \cdot \mathrm{cm}^{-3}$ & $\mathrm{~g} \cdot \mathrm{kg}^{-1}$ & $\mathrm{~g} \cdot \mathrm{kg}^{-1}$ & $\mathrm{~g} \cdot \mathrm{kg}^{-1}$ \\
0,270 & 0,176 & 0,094 & 1,116 & 302,56 & 63,4 & 634,04 \\
\hline
\end{tabular}

\section{Cultivation}

The tomato seedlings were tutored at 15 days after transplanting in a Mexican system (Wamser $e t$ $a l .$, 2007), with two stems per plant. Cleaning and pruning were performed once a week. Pruning of the apical bud was performed at 55 days after the transplanting of the seedlings, at the time when the plants presented 8-10 clusters.

The control of invasive plants was done manually when necessary. The phytosanitary control was performed preventively using the recommended products for the tomato crop according to the Brazilian Ministry of Agriculture, Livestock and Supply (MAPA).

\section{Characteristics evaluated}

The evaluated variables included plant height, yield, productivity, fresh mass and fruit diameter. The height of the plant was measured from the cervix to the apex by using a measuring tape (graded in centimeters) at 90 DAT. The yield was determined by the direct counting of the fruits on plants at 90 DAT and the value obtained was added to the number of fruits that had been harvested so far in each plant. The productivity and average fruit mass were determined by direct weighing of the harvested fruits. To obtain the average productivity, the average mass of the fruits harvested from each plant was multiplied by the number of fruits produced by the same plant (yield), to obtain the result in kilograms per plant. The diameter of the fruits was measured by using a digital pachymeter. The classification of fruits was performed according to the system proposed by the Ministry of Agriculture, Livestock and Supply (MAPA, 2000). This system was proposed for the marketing of tomatoes for consumption in natura among MERCOSUR member countries and in the Brazilian domestic market.

\section{Statistical analysis}

The data of the evaluated characteristics were submitted to the analysis of variance at the level of $5 \%$ significance. The effect of water tensions on the variables was analyzed by regression. Statistical analyzes were performed with the SAEG 9.1 software (SAEG, 2007).

\section{Results and Discussion}

All characteristics evaluated in the tomato plants were influenced by soil water tension, indicating that the productive stage of tomato can be affected by the water supply. For the plant height variable, a quadratic behavior was noted, with the highest value $(225.22 \mathrm{~cm})$ estimated by the regression curve at $23.64 \mathrm{kPa}$ (Fig. 1). Notably, up to $30 \mathrm{kPa}$ tension, the increase in height was less than $2 \%$. However, the plants submitted to the tension of $60 \mathrm{kPa}$ grew $20.9 \%$ less than the plants irrigated at $20 \mathrm{kPa}$ tension. The quadratic response of this variable demonstrates the heightened sensitivity of tomato to excess and deficit of water. Excessive water slides hamper roots aeration as well as favor nutrient loss through leaching (Marouelli \& Silva, 2006), which hinder the development of plants. On the other hand, water deficit can cause physiological changes in the plant. One of the first symptoms of water deficit is the reduction of turgescence, which in turn is associated with reduced cell extension and plant growth (Taiz \& Zeiger, 2009). These factors may have contributed to the reduction of plant height at tensions above $30 \mathrm{kPa}$ in this study.

Fruit yield was inversely proportional to soil water tension (Fig. 2A). At 15-kPa tension, the highest 


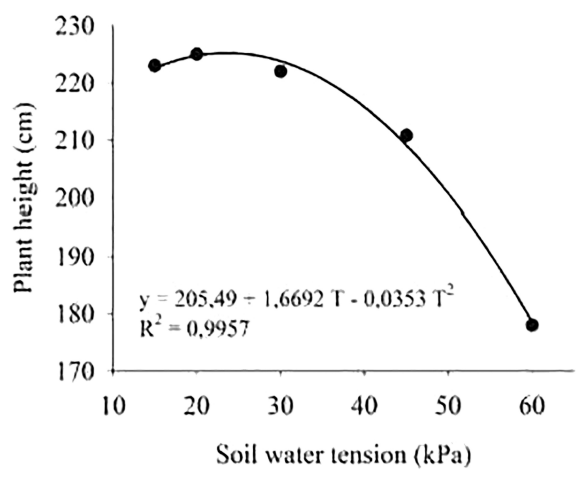

Figure 1. Height of tomato plants $(\mathrm{cm}) 90$ days after transplanting of the seedlings under different soil water tensions $(15,20,30,45$ and $60 \mathrm{kPa}$ ).
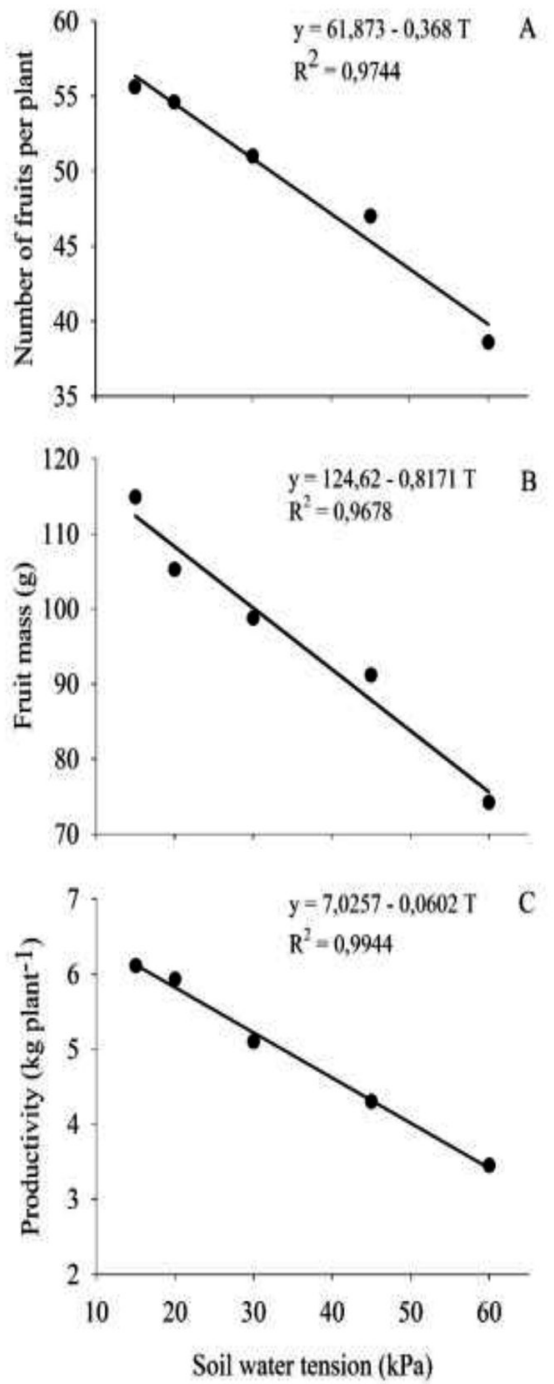

Figure 2. Number of fruits per plant (A), fresh fruit mass (B) and productivity $(\mathrm{C})$ of tomato plants under different soil water tensions $(15,20,30,45$ and $60 \mathrm{kPa})$ during the productive stage. production (55.6 fruits/plant) was obtained, followed by that at $20 \mathrm{kPa}$ tension (54.6). The tension of 60 $\mathrm{kPa}$ provided the lowest fruit yield (38.6), which was $30.5 \%$ lower than the production obtained at $15 \mathrm{kPa}$ tension. The reduction of yield due to increased soil water tension can be explained by lower plant growth, higher flower drop, and fruit miscarriage in plants submitted to water deficit conditions during the end of the flowering phase and the beginning of the fruiting phase (Marouelli et al., 1991; Prieto et al., 1999).

The average mass of fruits showed a linear behavior decreasing as a function of the increase in the water tension in the soil (Fig. 2B), which varied from $114.8 \mathrm{~g}$ under $15 \mathrm{kPa}$ tension to $74.18 \mathrm{~g}$ at $60 \mathrm{kPa}$ tension. The productivity of tomato plants depends on the number of fruits produced per plant and the fruit mass, presenting similar behavior to these two variables (Fig. 2C). The highest productivity of the plants was obtained at $15 \mathrm{kPa}(6.11 \mathrm{~kg} /$ plant $)$, which was $43.5 \%$ greater than that at $60 \mathrm{kPa}(3.45$ $\mathrm{kg} /$ plant), where there was a higher water deficit. Marouelli \& Silva (2006), in their work with tomatoes for processing, found larger fruit masses and productivity $\left(5.0 \mathrm{~kg} \mathrm{plant}^{-1}\right)$ at soil water tension of $10 \mathrm{kPa}$ during the fruiting stage. Marouelli \& Silva (2007) obtained higher productivities using the tensions of 35,12 and $15 \mathrm{kPa}$ in the vegetative, fruiting and maturation stages, respectively. The increase in fruit mass and productivity observed in the lower soil water tensions was justified by the composition of the tomato fruit, which had more than $90 \%$ water; therefore, higher water availability results in larger fresh fruit masses (Alvarenga, 2004). In addition, without any water restriction, the vegetable maintains its metabolic activity at adequate levels, capturing $\mathrm{CO}_{2}$ from the atmosphere and nutrients of the substrate, allowing better productive responses by the adequate production of photoassimilates (Melo et al., 2010).

The largest diameter of fruits was obtained at $15 \mathrm{kPa}$ tension, which decreased due to the increase of water tension in the soil (Fig. 3). It was verified that, in the tension of $15 \mathrm{kPa}$, the diameter was $63.21 \mathrm{~mm}$, while, at $60 \mathrm{kPa}$, the diameter corresponded to $52.92 \mathrm{~mm}$. However, according to the standards for the classification of tomato fruits of the Ministério da Agricultura, Pecuária e Abastecimento (MAPA, 2000), all fruits produced were classified as small, with a transverse diameter of 50-65 $\mathrm{mm}$. The reduction in fruit diameter as a function of increased water deficit 


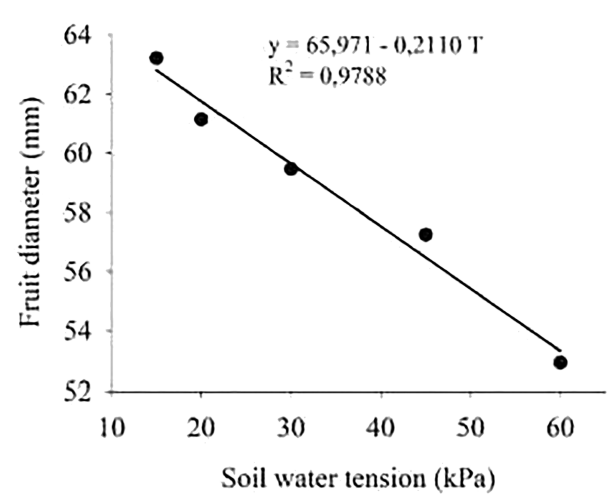

Figure 3. Fruit diameter of tomato plants under different soil water tensions $(15,20,30,45$ and $60 \mathrm{kPa})$ during the productive stage.

was also verified by Silva et al. (2013) and Koetz et al. (2010). According to Koetz et al. (2010), the diameter of the fruit can be increased or decreased through the applied water slide. However, slides that provide water deficit can cause reduction in the rate of division and cell elongation (Taiz \& Zeiger, 2009), resulting in smaller diameters of fruits.

\section{Conclusions}

All characteristics evaluated in the tomato plants were influenced by soil water tension, indicating that the productive stage of tomato can be affected by water supply. The tension of $15 \mathrm{kPa}$ potentiated the number of fruits produced, the productivity, the mass and the diameter of fruits. The greater height of plant was obtained with $23.64 \mathrm{kPa}$ tension.

\section{Acknowledgements}

The authors would like to thank the Coordenação de Aperfeiçoamento Pessoal de Nível Superior (CAPES) for granting a scholarship to the first author and the Fundação de Amparo à Pesquisa e Inovação do Espírito Santo (FAPES) for their financial support. They would also like to thank the Universidade Federal do Espírito Santo (UFES/CCAE) for the cost aid to implement the experiment and Joabe Martins Silva, Bruno Cesconetto, Pedro Esberard, João Paulo, and field assistants of CCAE, for their support in the installation and conduction of the experiment.

\section{Literature Cited}

Alvarenga, M.A.R.,

2004. Tomate: produção em campo, em casa-de-vegetação e em hidroponia. UFLA. Lavras, Brasil. 455 p.

Bernarndo, S.; Soares, A.A.; Mantovani, E.C.,

2009. Manual de irrigação, 8th ed. UFV Viçosa, Brasil. 625 p.

Carvalho, D.F.; Oliveira, L.F.C.,

2012. Planejamento e manejo da água na agricultura irrigada. UFV. Viçosa, Brasil. 240 p.

Embrapa,

2011. Manual de métodos de análise de solo, 2nd ed. Embrapa. Rio de Janeiro, Brasil. 230 p.

Koeppen, W.,

1948. Climatologia: Com um estúdio de los climas de la tierra. Fondo de cultura economica, Mexico. 478 p.

Koetz, M.; Masca, M.G.C.C.; Carneiro, L.C.; Ragagnin, V.A.; Sena Junior, D.G. de; Gomes, R.R.,

2010. Agronomic characteristcs and ${ }^{\circ}$ Brix of processing tomato fruits under drip irrigation in the southwest of Goiás. Revista Brasileira de Agricultura Irrigada, 4:14-22.

MAPA, Ministério da Agricultura, Pecuária e Abastecimento, 2000. Lei no 9.972, 25 de maio de 2000. Available in: www. agricultura.gov.br. Consulted in: 10/june/2018.

Marouelli, W.A.; Silva, H.R.; Oliveira, C.A.S., 1991. Produção de tomate industrial sob diferentes regimes de umidade no solo. Pesquisa Agropecuária Brasileira 26: 1531-1537.
Marouelli, W.A.; Silva, W.L.C.,

2007. Water tension thresholds for processing tomatoes under drip irrigation in Central Brazil. Irrigation Science 25, 411-418.

Marouelli, W.A.; Silva, W.L.C.,

2006. Response of drip-irrigated processing tomatoes to water regimes during crop fructification stage. Horticultura Brasileira 24, 342-346.

Melo, A.S. de; Suassuna, J.F.; Fernandes, P.D.; Brito, M.E.B.;

Suassuna, A.F.; Aguiar Netto, A. de O.,

2010. Vegetative growth, stomatal resistance, photosynthetic efficiency and yield of watermelon plants under different water levels. Acta Scientiarum. Agronomy 32: 73-79.

Novais, R.F.; Neves, J.C.L.; Barros, N.F.,

1991. Ensaio em ambiente controlado, In: Oliveira, A.J., Garrido, W.E., Araújo, J.D., Lourenço, S. (Eds.), Métodos de Pesquisa Em Fertilidade Do Solo. Embrapa, Brasília, pp. 189-254.

Prezotti, L.C.; Gomes, J.A.; Dadalto, G.G.; Oliveira, J.A., 2007. Manual de Recomendação de Calagem e Adubação para o Estado do Espírito Santo - 5a aproximação. SEEA/ INCAPER/CEDAGRO, Vitória, Brasil. 301 p.

Prieto, M.H.; López, J.; Ballesteros, R.; Junta de Extremadura, S.I.A., 1999. Influence of irrigation system and strategy of the agronomic and quality parameters of the processing tomatoes in Extremadura. Acta Horticulturae, 487 (487): 575-579. 
SAEG, 2007. SAEG: sistema para análises estatísticas, versão 9.1: Fundação Arthur Bernardes. UFV. Viçosa, Brasil.

Santana, M.J.; Vieira, T.A.,

2010. Tomato response irrigated with different levels of soil water replacement. Irriga, 15: 443.

Silva, J.M. da; Ferreira, R.S.; Melo, A.S. de; Suassuna, J.F.; Dutra, A.F.; Gomes, J.P.,

2013. Cultivation of tomato in greenhouse under different replenishment rates of evapotranspiration. Revista Brasileira de Engenharia Agrícola e Ambiental, 17: 40-46.
Taiz, L.; Zeiger, E., 2009. Fisiologia Vegetal, 4th ed. Artmed. Porto Alegre, Brasil. 819 p.

van Genuchten, M.T.,

1980. A Closed-form Equation for Predicting the Hydraulic Conductivity of Unsaturated Soils1. Soil Science Society of America Journal, 44: 892.

Wamser, A.F.; Mueller, S.; Becker, W.F.; Santos, J.P. dos, 2007. Fruits production of tomatoes as a result of plant training systems. Horticultura Brasileira, 25: 238-243. 